\title{
Pengaruh Kombinasi Komposisi Media Organik dan Konsentrasi Nutrisi terhadap Daya Hasil Tanaman Melon (Cucumis melo L.)
}

DOI 10.18196/pt.2015.041.67-72

\author{
Khoirul Bariyyah*, Sigit Suparjono dan Usmadi \\ Program Studi Agronomi, Fakultas Pertanian, Universitas Jember, \\ Jl. Kalimantan No. 37, Jember, Jawa Timur, Indonesia, Telp: 0331-334054, Fax: 0331-338422, \\ ${ }^{*}$ Corresponding author, e-mail: riyamanis.27@gmail.com
}

\begin{abstract}
ABSTRAK
Penelitian ini bertujuan untuk mengetahui interaksi kombinasi komposisi media organik dan konsentrasi nutrisi terhadap daya hasil tanaman melon. Penelitian disusun dalam rancangan faktorial 4 × 4 menggunakan Rancangan Acak Lengkap dengan tiga ulangan. Faktor pertama adalah komposisi media yang terdiri dari empat taraf yaitu M1 (bokashi 90\%, cocopeat 5\%, arang sekam 5\%), M2 (bokashi 80\%, cocopeat 10\%, arang sekam 10\%), M3 (bokashi 70\%, cocopeat 15\%, arang sekam 15\%), dan M4 (bokashi 60\%, cocopeat 20\%, arang sekam 20\%), sedangkan faktor kedua adalah konsentrasi nutrisi terdiri dari empat taraf yaitu KO (kontrol/tanpa tambahan nutrisi), K1 (2 g/l), K2 (4 g/l), dan K3 (6 g/l). Bibit melon Varietas 434 dipindahtanamkan ke polybag 10 kg hingga panen. Hasil penelitian menunjukkan bahwa kandungan klorofil perlakuan M1 memiliki hasil yang lebih tinggi bila dibandingkan dengan varietas lain, namun kandungan gula tertinggi diperoleh pada perlakuan M3. Kombinasi bokashi antara bokashi:cocopeatarang sekam sebesar 60:20:20\% dengan konsentrasi nutrisi 4 gram/liter dapat meningkatkan tebal daging buah.

Kata kunci: Melon, Media Tumbuh, Konsentrasi Nutrisi
\end{abstract}

\begin{abstract}
This research was addressed to study the effect of plant growth media composition and nutrients concentration on yield of Cucumis melo L. The research was designed in complete factorial test of $4 \times 4$ with three replicates. Mixed growth media of bokashi:cocopeat:husk charcoal were tested in four compositions, i.e. 90\%:5\%:5\% (M1), 80\%:10\%:10\%(M2), 70\%:15\%:15\% (M3) and 60\%:20\%:20\% (M4) respectively. The other tested factor was nutrients concentraion that consists of four levels, i.e. control/no nutrient given (KO), $2 \mathrm{~g} / \mathrm{L}(\mathrm{K} 1$ ), $4 \mathrm{~g} / \mathrm{L}$ (K2) and $6 \mathrm{~g} / \mathrm{L}$ (K3). The Action 434 variety of Cucumis melo L. seedlings were then transplanted into 10 kg's polybag and allowed to grow till harvested. The results showed that Chlorophyll content of M1 plants were higher than others, but the highest sugar content was resulted by M3 plants, and the highest thick of flesh fruit was resulted by interaction 60\% bokashi:20\% cocopeat:20\% husk charcoal with $4 \mathrm{~g} / \mathrm{L}$ nutrient concentration.

Keywords: Cucumis melo L., Growth media, Nutrient concentration
\end{abstract}

\section{PENDAHULUAN}

Melon merupakan tanaman $\mathrm{C}_{3}$, karena proses fotosintesisnya menghasilkan senyawa karbon yang beratom 3 sebagai produk utamanya. Tanaman ini tidak tahan terhadap intensitas cahaya yang sangat tinggi dan menghendaki sinar matahari berkisar antara 10-12 jam/hari, kelembaban berkisar antara 70-80\%. Tanaman ini akan berproduksi dengan optimal pada media yang mengandung bahan organik, karena akar tanaman akan tumbuh sempurna.

Perubahan iklim yang diakibatkan oleh pemanasan global menyebabkan peningkatan intensitas kejadian iklim ekstrim (El-Nino dan La-Nina)

dan ketidakteraturan musim. Adanya perubahan iklim dapat menyebabkan terjadinya perubahan cuaca, sehingga periode musim tanam menjadi berubah. Hal ini akan mengakibatkan budidaya tanaman melon harus beradaptasi dengan perubahan pola tanam tersebut. Upaya yang dilakukan supaya budidaya melon dapat dilakukan dengan optimal adalah dengan menggunakan bahan organik sebagai media tanam dengan tambahan nutrisi yang tepat merupakan salah satu strategi reduksi dan adaptasi dari perubahan iklim dalam budidaya tanaman melon. Media organik merupakan media tanam 
yang sebagian besar atau seluruhnya terdiri atas bahan organik yang berasal dari tanaman dan atau hewan yang telah melalui proses fermentasi. Sebagai media tanam, bahan tersebut mampu menyediakan unsur-unsur hara esensial yang mudah diserap oleh tanaman. Media tanam organik diduga dapat memperlambat perubahan iklim karena dapat mengurangi emisi gas rumah kaca akibat penggunaan pupuk sintetis menurun. Media tanam organik mempunyai kemampuan menyediakan kapasitas tukar kation (cation exchange capacity), kapasitas memegang air, mampu menyediakan unsur hara makro dan mikro, aerasi dan darinase baik, serta menyediakan oksigen. Beberapa bahan organik yang dapat digunakan sebagai bahan tanam adalah bokashi, arang sekam, dan cocopeat. Bokashi merupakan pupuk kompos yang dihasilkan dari proses fermentasi atau peragian bahan organik dengan teknologi EM (Effective Microorganism). Media bokashi mengandung unsur hara makro dan mikro yang bermanfaat bagi tanaman, selain itu juga memiliki pori-pori makro dan mikro yang hampir seimbang sehingga sirkulasi udara yang dihasilkan cukup baik serta memiliki daya serap air yang tinggi.

Arang sekam memiliki kandungan karbon yang tinggi sehingga membuat media tanam menjadi gembur. Penambahan sekam membuat struktur media menjadi remah dan akar leluasa dalam pertumbuhannya (Tim Karya Tani Mandiri, 2010). Arang sekam juga dapat digunakan sebagai bufer (penyangga) jika terjadi kekeliruan dalam pemberian unsur hara yang terkandung di dalam pupuk, sehingga bisa segera dinetralisir dan diadaptasikan. Sabut kelapa merupakan media yang mampu mengikat dan menyimpan air dengan kuat, sesuai untuk daerah panas, dan mengandung unsur-unsur hara esensial, seperti kalsium (Ca), magnesium (Mg), kalium
$(\mathrm{K})$, natrium $(\mathrm{Na})$, dan fosfor $(\mathrm{P})$. Serbuk kelapa mampu menyimpan air 8 kali dari beratnya sehingga media dapat lebih lembab (Tim Karya Tani Mandiri, 2010). Kombinasi media tanam organik mampu menyediakan nutrisi yang lengkap bagi tanaman tetapi dalam jumlah sedikit, oleh karena itu diperlukan tambahan nutrisi supaya kebutuhan unsur hara makro dan mikro terpenuhi sehingga hasil buah melon yang diperoleh maksimal. Penelitian ini bertujuan untuk mengetahui interaksi kombinasi komposisi media organik dan konsentrasi nutrisi terhadap daya hasil tanaman melon.

\section{BAHAN DAN METODE}

Penelitian dilaksanakan di green house Jurusan Budidaya Pertanian Fakultas Pertanian Universitas Jember pada ketinggian 89 meter di atas permukaan laut. Bahan yang digunakan dalam penelitian ini adalah benih melon varietas Action 434, bokashi, arang sekam, cocopeat, dan pupuk power nutrition. Proses penanaman dan pemeliharaan tanaman melon dilakukan sesuai dengan cara budidaya melon.

Penelitian disusun dalam rancangan faktorial 4 x 4 menggunakan Rancangan Acak Lengkap dengan tiga ulangan. Faktor pertama adalah komposisi media yang terdiri dari empat taraf yaitu M1 (bokashi 90\%, cocopeat 5\%, arang sekam 5\%), M2 (bokashi 80\%, cocopeat 10\%, arang sekam 10\%), M3 (bokashi 70\%, cocopeat $15 \%$, arang sekam 15\%), dan M4 (bokashi 60\%, cocopeat 20\%, arang sekam 20\%), sedangkan faktor kedua adalah konsentrasi nutrisi terdiri dari empat taraf yaitu $\mathrm{KO}$ (kontrol/tanpa tambahan nutrisi), K1 (2 gram/liter), K2 (4 gram/liter), dan K3 (6 gram/liter).

Parameter yang diamati adalah kandungan total klorofil, berat buah, volume buah, tebal daging, kadar gula total. Data yang diperoleh 
dianalisis dengan menggunakan sidik ragam, apabila terdapat perbedaan yang nyata diantara perlakuan dilanjutkan dengan Uji Duncan taraf $5 \%$.

\section{HASIL DAN PEMBAHASAN}

\section{Kandungan Total Klorofil}

Komposisi media memberikan pengaruh yang sangat nyata terhadap kandungan klorofil total (Gambar 1), sedangkan konsentrasi nutrisi dan interaksi antara komposisi media dengan konsentrasi nutrisi tidak memberikan pengaruh yang nyata terhadap kandungan klorofil total daun melon.

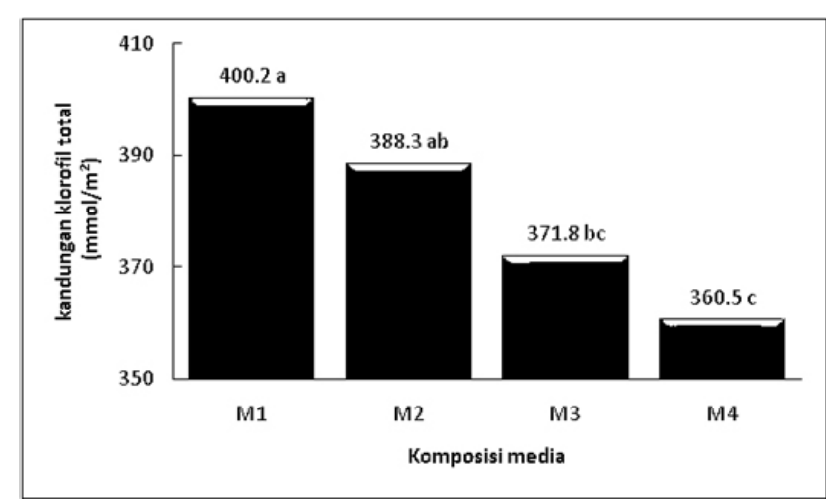

Gambar 1. Pengaruh komposisi media terhadap kandungan klorofil total

Keterangan: Komposisi media M1, M2, M3, dan M4 mengacu pada Metode Penelitian, demikian berlaku untuk gambar sejenis dalam naskah ini. Angka-angka yang diikuti huruf yang sama menunjukkan tidak berbeda nyata pada á $=5 \%$.

Rerata kandungan klorofil total daun melon pada perlakuan M1, M2, M3, dan M4 berturutturut adalah 400,2; 388,3; 371,8 dan 360,5

$\left(\mathrm{imol} / \mathrm{m}^{2}\right)$. Kandungan klorofil total tertinggi ditunjukkan pada perlakuan M1 (90\% bokahi, 5\% cocopeat, 5\% arang sekam), sedangkan terendah ditunjukkan oleh perlakuan M4 (60\% bokahi, $20 \%$ cocopeat, $20 \%$ arang sekam).

Tinggi dan rendahnya kandungan total klorofil pada daun melon diduga disebabkan oleh komposisi bokashi dalam media. Bokashi mengandung EM atau mikroorganisme perom- bak bahan organik sehingga dapat meningkatkan ketersediaan unsur hara dalam media tanam, seperti unsur nitrogen dan $\mathrm{Mg}$. Bokashi mengandung unsur $\mathrm{N}$ 1,95\% dan unsur $\mathrm{Mg}$ 0,7\%, yang merupakan komponen utama penyusun klorofil daun. Nitrogen merupakan hara esensial yang berfungsi sebagai bahan penyusun klorofil dan meningkatkan ukuran daun (Nyapka, dkk., 1988).

Pigmen klorofil berfungsi menyerap energi cahaya matahari yang berperan dalam proses fotosintesis. Energi cahaya matahari yang diserap oleh pigmen klorofil akan dimanfaatkan untuk memecah molekul air menjadi bentuk $\mathrm{H}_{2}$ dan $\mathrm{O}_{2}$ yang disebut fotolisis. $\mathrm{H}_{2}$ yang dihasilkan digunakan untuk membentuk $\mathrm{NADPH}_{2}$. Selain itu, energi tersebut juga digunakan untuk proses fosforilasi yaitu proses mengubah ADP menjadi ATP. Pada tanaman melon (tanaman $\mathrm{C}_{3}$ ) bentuk senyawa yang terakumulasi dari hasil fotosintesis adalah sukrosa yang tersimpan dalam buah.

\section{Berat dan Volume Buah}

Perlakuan kombinasi komposisi media dengan konsentrasi nutrisi tidak memberikan pengaruh nyata terhadap berat dan volume buah melon. Rerata hasil berat buah dari perlakuan kombinasi media M1K0, M1K2, M1K3, M1K4, $\mathrm{M} 2 \mathrm{~K} 0, \mathrm{M} 2 \mathrm{~K} 2, \mathrm{M} 2 \mathrm{~K} 3, \mathrm{M} 2 \mathrm{~K} 4, \mathrm{M} 3 \mathrm{~K} 0, \mathrm{M} 3 \mathrm{~K} 2$, M3K3, M3K4, dan M4K0, M4K2, M4K3, M4K4 berturut-turut adalah 1,$05 ; 0,87 ; 0,76 ; 0,99$; 1,$0 ; 0,88 ; 1,05 ; 0,82 ; 0,82 ; 1,0 ; 1,06 ; 1,06 ; 1,04$; 0,$89 ; 1,24 ; 1,05 \mathrm{~kg}$. Sementara rerata volume buah berturut-turut adalah 960,67; 1012; 1038; 1070,$5 ; 1088,33 ; 1091,67 ; 1228,50 ; 1232,50$; 1246,$67 ; 1272 ; 1291,83 ; 1318,33 ; 1319,33$; 1329,$82 ; 1381,33 \mathrm{~m}^{3}$. Berat buah melon varietas Action 434 tidak dapat mencapai berat maksimal (2,6 kg). Hal ini diduga disebabkan oleh serapan unsur $\mathrm{P}$ terhambat karena $\mathrm{pH}$ media 
tanah rendah (Gambar 4), hal ini didukung oleh Ardika dkk. (2008) yang menyatakan bahwa faktor yang mempengaruhi tersedianya P untuk tanaman yang terpenting adalah $\mathrm{pH}$ tanah. Kecukupan unsur hara fosfor dalam bentuk cadangan makanan pada batang akan membantu merangsang pembentukan buah (Kushendarto dan Darwin, 2009). Kebutuhan unsur P yang kurang tercukupi diduga sebagai penyebab ukuran buah kecil.

\section{Tebal Daging Buah}

Interaksi antara macam komposisi media organik dengan konsentrasi larutan nutrisi memberikan pengaruh sangat nyata terhadap ketebalan daging buah melon. Interaksi menunjukkan bahwa tebal daging tertinggi terdapat pada perlakuan M3K3 yaitu 3,617 cm dan M4K2 yaitu 3,6 cm, sedangkan tebal daging terendah terdapat pada perlakuan M1K2 yaitu 2,5 cm (Gambar 2). Perlakuan M3K3 dan M4K2 menunjukkan hasil terbaik karena media tanam M3 dan M4 komposisi dari campurannya seimbang sehingga media porus dan dapat mempertahankan kelembaban dan nutrisi yang disiramkan mampu ditahan dalam media dan tersedia bagi tanaman melon sehingga mampu meningkatkan hasil tanaman dalam hal ini tebal daging buah.

Tebal daging buah yang terbentuk pada buah melon dipengaruhi oleh nutrisi yang diserap oleh tanaman. Penyerapan unsur hara oleh akar akan ditranslokasikan ke semua organ tanaman. Hasil dari penyerapan unsur hara akan dipindahkan ke dalam buah yang sedang berkembang (Campbell dkk., 2003). Suplai unsur hara optimal dengan perimbangan yang baik dari semua unsur hara merupakan jaminan bagi kuantitas dan kualitas hasil panen (Wijaya, 2008). Kualitas buah seperti kadar gula, aroma, rasa, berat buah, tebal daging buah dan volume buah suatu tanaman ditentukan nutrisi tanaman yang diserap oleh tanaman yang pada ahirnya dibawa oleh hasil panen. Kemudahan tanaman untuk menyerap unsur hara di pengaruhi oleh media tanam.

\section{Kadar Gula Total}

Hasil analisis menunjukkan bahwa komposisi media organik memberikan pengaruh yang nyata terhadap kadar gula total buah melon. Kombinasi komposisi media organik dengan konsentrasi nutrisi memberikan pengaruh berbeda tidak nyata terhadap kadar gula buah melon.

Rerata kadar gula total buah melon pada perlakuan M1, M2, M3, dan M4 adalah 19,38;

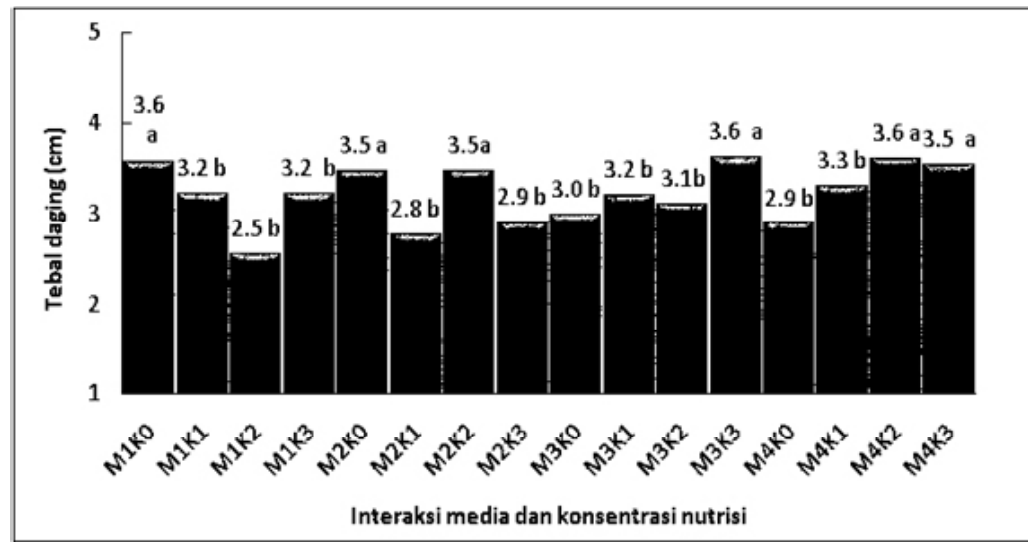

Gambar 2. Pengaruh kombinasi komposisi dengan konsentrasi nutrisi terhadap tebal daging buah. 
15,92; 32,97 dan 30,25 \% (Gambar 3). Kadar gula total buah melon tertinggi ditunjukkan pada perlakuan M3 (70\% bokashi, 15\% cocopeat, $15 \%$ arang sekam) dan terendah pada perlakuan M2 (80\% bokashi, 10\% cocopeat, 10\% arang sekam).

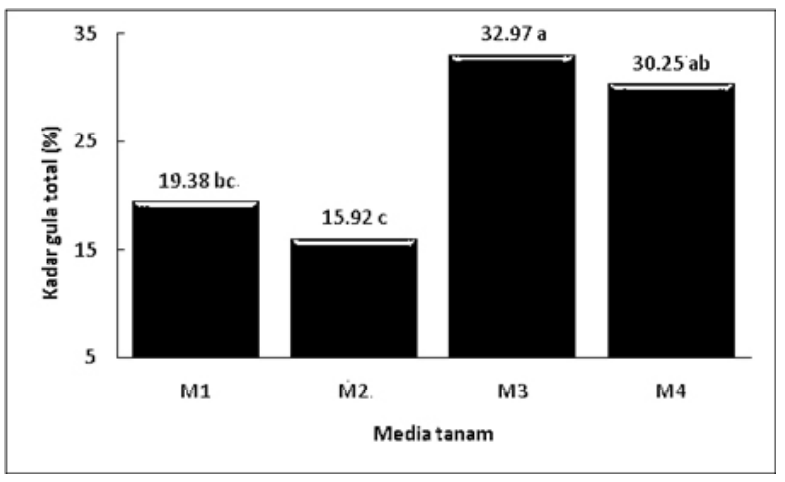

Gambar 3. Pengaruh komposisi media terhadap kadar gula total.

Keterangan: Komposisi media M1, M2, M3, dan M4. Angka-angka yang diikuti huruf yang sama menunjukkan tidak berbeda nyata pada á $=5 \%$.

Komposisi media organik sebagai media tanam mengandung unsur hara makro dan mikro yang tersedia bagi tanaman. Bokashi mengandung unsur P 1,73\% dan unsur K 1,2 \%. Unsur hara tersebut diserap tanaman dalam bentuk ion. Menurut Pantastico (1975) dalam Purwanto (2005) ketersediaan unsur $\mathrm{K}$ yang rendah dalam tanaman dapat menurunkan kulitas dan produksi buah seperti kadar gula dan ukuran buah. Buah yang sedang tumbuh adalah tempat penyimpanan gula. Buah yang sedang tumbuh memerlukan banyak makanan sehingga buah bisa memonopoli semua sumber gula yang ada di sekitarnya, nutrisi yang tersedia dalam media tanam dapat meningkatkan kadar gula pada buah melon.

Komposisi media M3 menunjukkan kadar gula tertinggi dibandingkan dengan M1. Rendahnya kadar gula total dalam buah M1 dan M2 diduga disebabkan penyerapan $\mathrm{P}$ dan $\mathrm{K}$ terhambat karena $\mathrm{pH}$ media tanam rendah. Media tanam $\mathrm{M} 1, \mathrm{M} 2$, M3, dan M4 mempunyai $\mathrm{pH}$ rerata 5; 5; 5,3; 5,3 (Gambar 4).

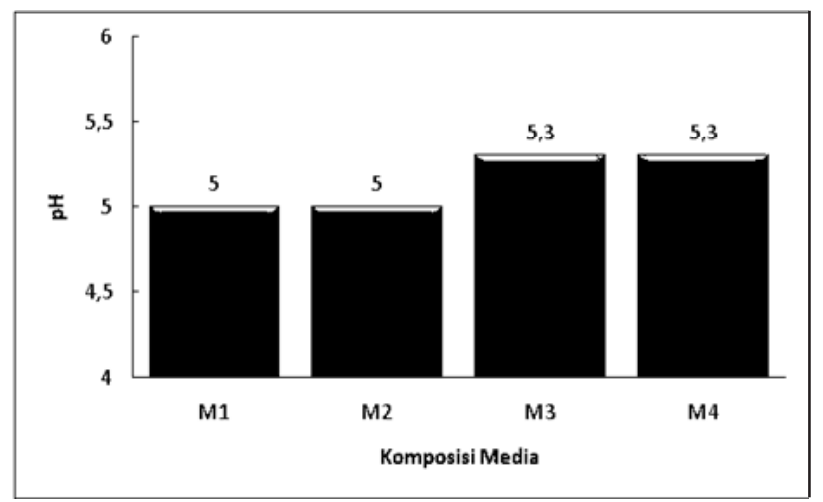

Gambar 4. pH setiap komposisi media organik

Hal ini disebabkan media tanam mengandung $100 \%$ bahan organik yang terdiri dari bokashi, cocopeat, dan arang sekam. Unsur K akan mudah tercuci pada $\mathrm{pH}$ rendah. Menurut Yusra (2005), nilai $\mathrm{pH}<5,5 \mathrm{Fe}, \mathrm{Al}$ dan $\mathrm{Mn}$ dalam media berada dalam bentuk ion-ion $\mathrm{Fe}^{2+}$, $\mathrm{Al}^{3+}$ dan $\mathrm{Mn}^{2+}$. Jumlah ini meningkat dengan menurunnya nilai $\mathrm{pH}$ tanah. Menurut Buckman dan Brady (1984) bentuk ion tersebut dapat bertindak sebagai pencegah ketersediaan $\mathrm{P}$ bagi tanaman melalui reaksi yang menghasilkan suatu endapan yang sukar larut, sehingga $P$ tidak tersedia bagi tanaman.

\section{SIMPULAN}

1. Media organik dengan komposisi bokashi, cocopeat, arang sekam sebesar 60:20:20\% dapat meningkatkan kandungan gula total pada buah melon.

2. Kombinasi bokashi antara bokashi:cocopeat:arang sekam sebesar 60:20:20\% dengan konsentrasi nutrisi 4 gram/liter dapat meningkatkan tebal daging buah. 


\section{DAFTAR PUSTAKA}

Ardika, R., Sri. N. H. U., dan Benito, H. P., 2008. Pengaruh Seresah dan Takaran Pupuk P terhadap P Tersedia dan Serapan P Jagung pada Tanah Napalan Bangunjiwo Bantul. Ilmu Tanah dan Lingkungan 8 (2) : 114-120.

Buckman, H.O dan L.D, Brady., 1984. IImu Tanah Terjemahan Soegman. Braharta Aksara. Jakarta

Campbel, Reece, dan Mitchell. 2003. Biologi. Erlangga, Jakarta. Kushendarto dan Darwin H. P. 2009. Pengaruh Pemupukan Fosfor dan Kalium Terhadap Pertumbuhan dan Produksi Buah Naga. Seminar Hasil penelitian dan Pengabdian Masyarakat. Unila.

Nyapka, M. Y., dkk. 1988. Kesuburan Tanah. Universitas Lampung, Bandar Lampung.

Purwanto, 2005. Pengaruh Pupuk Majemuk NPK dan Bahan Pemantap Tanah Terhadap Hasil dan Kualitas Tomat Varietas Intan. Jurnal Penelitian UNIB 11 (1) : 54-56.

Tim Karya Tani Madiri, 2010. Pedoman Budidaya secara Hidroponik. Nuansa Aulia. Bandung.

Wijaya, K. A. 2008. Nutrisi Tanaman. Prestasi Pustaka, Jember. Yusra. 2005. Pengaruh Lateks dan Cendawan Mikoriza terhadap P-Total, P-Tersedia dan $\mathrm{pH}$ Tanah Ultisols. The Effect of Latex and Mycorhyza Fungus on Total P, Available and pH of Ultisols Soil.Jurnal IImiah Pertanian KULTURA. 40(2): 100-105. 